\title{
Visceral Gout in Coastal and Oceanic Seabirds in Paraná, Southern of Brazil
}

\author{
Daniela Farias da Nóbrega', Isabela Guarnier Domiciano', \\ Camila Domit ${ }^{1}$ \& Ana Paula Frederico Rodrigues Loureiro Bracarense ${ }^{1,2}$
}

\begin{abstract}
Background: Owing to the abundance, wide distribution, long life cycles and higher positions in the throfic levels, seabirds are considered sentinels of hazards and negative anthropogenic impacts to marine ecosystems. Gout is a common disease affecting birds, but also occurs in other taxa, including mammals and reptiles. The aim of this study was to elucidate the occurrence and pathological findings of gout cases in different species of seabirds, including biological and ecological factors that may contribute to disease.

Cases: The urate crystals were observed in ten seabirds stranded, classified in eight species: four oceanic species - two Puffinus puffinus, one Macronectis giganteus, one Thalassarche melanophris, one Calonectris sp. and four coastal species - one Fregata magnifiscens, two Sula leucogaster, one Phalacrocorax brasilianus and one Rynchops niger. A total of seven animals were stranded alive and three were found dead; four animals were male and six were female; six were juveniles and four were mature. The nutritional condition was cachectic in four animals, poor in five and fair in one. The main clinical sign in alive animals was dehydration $(7 / 7 ; 100 \%)$. The treatment consisted of standard support including fluid therapy and temperature stabilization; in addition, vitamins, amino acids, minerals and antibiotics (sulfonamide or enrofloxacin) were given, but the animals died between 1 and 13 days after rehabilitation entrance. Gout was associated with cachectic condition and autumn stranding (in comparison with summer stranding). The main macroscopic findings were observed in the kidneys, which were whitish and enlarged and all had microscopic evidence of multifocal, mild to marked renal crystal urate deposition. In two cases, urates deposition were observed in multiple organs, including liver, spleen, lung, epicardium and kidney, indicating severe visceral gout. The gout was considered the ultimate cause of death in three cases, and in the remaining cases, the main lesion associated with death was trauma $(n=2)$, infectious enteritis $(\mathrm{n}=2)$, systemic infection $(\mathrm{n}=1)$, myocardial necrosis $(\mathrm{n}=1)$ and cachexia syndrome. The contributing factors for urate deposition were metabolic imbalances, chronic dehydration and overdoses of protein supplements.

Discussion: The ten cases described above constitute a rare report of visceral gout in free-living and in rehabilitation seabirds and contributes towards understanding the prevalence and pathogeny of gout in stranded oceanic and coastal animals off southern Brazil. Similar prevalence of gout was observed among free-ranging birds of other reports, but it was considered lower when compared to $21.5 \%$ and $23.3 \%$ affecting captive/broilers. The difference observed may be influenced by the population analysed, but also by the gout pathogeny and environmental conditions. Among the possible causes of gout, dehydration was observed in all gout-affetected animals stranded alive, a change usually observed in debilitated/stranded animals that probably has contributed to the disease. Additionally, the poor/cachectic condition noticed in the majority of seabirds indicates a nutritional disorder, also a cause promoting visceral gout. In the present study, accumulation of urate crystals was predominantly limited to the kidneys and associated with inflammatory infiltrate, suggesting a chronic process. The results of this study support the hypothesis that visceral gout is a complex consequence of multiple factors affecting both free-living and rehabilitated seabirds. Therefore, further investigation of the other possible causes, frequency and consequences for coastal and oceanic species is indispensable.
\end{abstract}

Keywords: gout, nephropathy, seabirds, urate crystals. 


\section{INTRODUCTION}

The seabirds that occur along the Paraná coast, southern Brazil, comprise about a third of all registered marine avian species off the entire Brazilian coast $[27,41]$. This high diversity area is considered part of a World Heritage Site by UNESCO and is used by migrating and resident seabirds for breeding, feeding and resting [14,40].

Owing to the wide distribution, long life cycles and higher positions in the trophic levels, seabirds are considered sentinels of hazards and negative anthropogenic impacts to marine ecosystems [5]. Therefore, health assessments of seabirds can help to determine the levels of environmental contamination and degradation, as to apprise about diseases and the presence of pathogenic and/or zoonotic agents [5].

The serum concentration of uric acid may vary according to age, sex, species, feeding, reproductive status, trauma and stress $[4,13]$ but a disbalance of production and excretion may lead to gout, a metabolic disorder that results in hyperuricemia and urates deposition in several tissues [22,38]. Gout is a common disease affecting birds in general, but also occurs in other taxa, including mammals and reptiles $[9,25]$.

Visceral gout is one of the main illnesses affecting poultry production and presents high mortality $[3,38]$, but information describing gout and its potential causes and effects in free-ranging and in rehabilitation seabirds are scarce $[1,20]$.

The aim of this study was to elucidate the occurrence and pathological findings of gout cases in different species of seabirds, including biological and ecological factors that may contribute to the disease occurrence.

\section{CASES}

Between August 2015 and August 2018, a daily monitoring ocean beaches $(\sim 100 \mathrm{~km})$ and islands in Paranaguá Estuarine Complex (25 $44^{\prime}$ S and $48^{\circ} 29^{\prime} \mathrm{W}$ ) for stranded seabirds was performed, as part of an ongoing beach-monitoring program (PMP-BS). The PMP-BS is one of the monitoring programs required by Brazil's federal environmental agency, IBAMA, for the environmental licensing process of the oil production and transport by Petrobras at the Santos Basin pre-salt province (ABIO-Renovação-Nº640/2015). Clinical parameters of animals stranded alive were evaluated. All dead specimens were autopsied and examined for individual information, including sex (female and male - gross and histological evaluation), stage of development (mature and immature - macroscopic and histological evaluation), nutritional status (according to pectoralis muscle volume [28]).

Pathological findings were evaluated and samples of main organs were collected (lung, air sacs, heart, spleen, liver, pancreas, esophagus, stomach, intestines, thymus, thyroid, parathyroid, kidney, adrenal gland, skin, skeletal muscle and central nervous system), fixed in $10 \%$ buffered formalin solution, routinely processed, embedded in paraffin, and stained with hematoxylin and eosin. The histopathological analysis was performed and the presence of urate crystals was investigated in multiple tissues. Furthermore, contingency tables analyses using Fisher's exact test (two-tailed) were used to test the hypothesis that gout frequency was associated with sex, stage of development, nutritional status, stranding season and year. The SPSS Statistics 25 software were used for statistical analysis. The alpha level was set at 0.05 .

The urate crystals were observed in ten of 315 seabirds (3.2\%) stranded and autopsied, classified in eight species: four oceanic species - two Puffinus puffinus, one Macronectis giganteus, one Thalassarche melanophris, one Calonectris sp. and four coastal species - one Fregata magnifiscens, two Sula leucogaster, one Phalacrocorax brasilianus and one Rynchops niger. A total of seven animals were stranded alive and three were found dead; four animals were male and six were female; six were juveniles and four were mature. The nutritional condition was cachectic in four animals, poor in five and fair in one. Gout was associated with cachectic condition $(P=0.044)$ and autumn stranding $(P=0.030)$ (in comparison with summer stranding).

The main clinical sign in alive animals was dehydration $(7 / 7 ; 100 \%)$. The treatment consisted of standard support including fluid therapy and temperature stabilization; in addition, vitamins, amino acids, minerals $\left(\text { Aminomix }{ }^{\circledR}\right)^{1}$, and antibiotics (sulfonamide or enrofloxacin) were given, but the animals died between 1 and 13 days after rehabilitation entrance.

The main macroscopic findings varied, and gout was considered the ultimate cause of death in three cases. In the remaining cases, the main lesion associated with death was trauma $(n=2)$, infectious enteritis $(n=2)$, systemic infection $(n=1)$, myocardial necrosis $(n=1)$ and cachexia syndrome $(n=1)$. Despite 
the cause of death, in seven cases the macroscopic findings included enlarged and diffusely whitish kidneys (Figure 1A). In all cases the microscopic findings comprised mild to severe multifocal weakly eosinophilic and radiating structures replacing the renal parenchyma surrounded by necrosis and histiocytic infiltrate (gouty tophi) [Figure 1B]. The gouty tophi were predominantly limited to the kidneys $(\mathrm{n}=8)$, and also observed in multiple organs, including liver, spleen, lung, epicardium and kidney in two cases, indicating severe visceral gout. Additionally, mild to moderate number of parasite trematodes (eggs and mature stages) $(n=2)$ or protozoal megaloschizonts $(n=1)$ were observed in the lumen of the renal collecting ducts.

\section{DISCUSSION}

The ten cases described above constitute a rare report of visceral gout in free-living and in rehabilitation seabirds and contributes towards understanding the dispersion and pathogeny of gout in stranded oceanic and coastal species off southern Brazil. This is the first report of the disease in seven species off Brazil, except for Puffinus puffinus [12]. The Fregata magnifiscens, Sula leucogaster and Phalacrocorax brasilianus are usually observed in foraging or breeding areas in the Paraná coast [14], but Macronectis giganteus, $P$. puffinus, Thalassarche melanophris, Calonectris sp. and Rynchops niger are migratory and transboundary species that inhabit pelagic and coastal areas (IUCN red list, 2019-2). The most cases of gout in the fall is probably due to the migratory seasonality of the registered species [15].

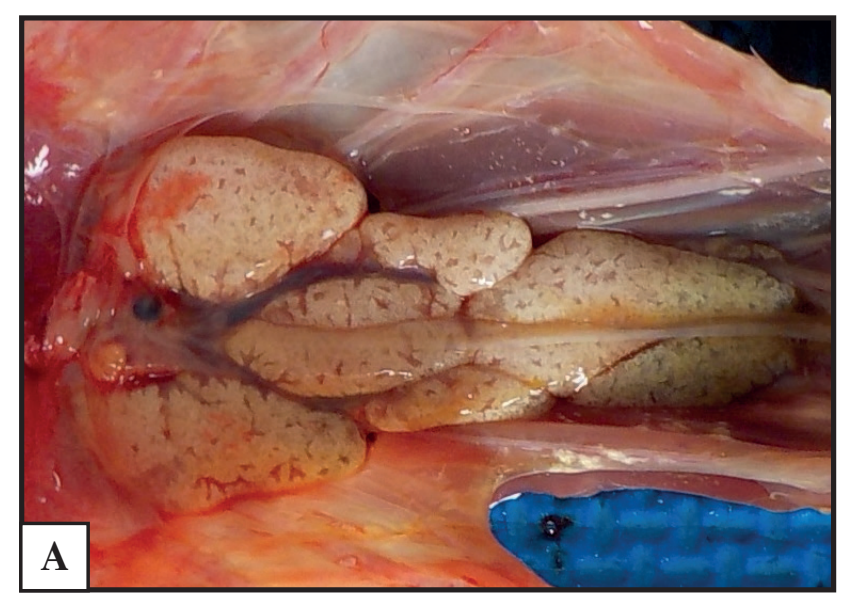

The results observed here are both consistent and divergent with previous reports of visceral gout in seabirds and other wild and captive birds (e.g.poultry) $[3,17,26,29,30,34,35,42]$. Although scarse, similar prevalence of gout was observed among free-ranging birds, including 3.2\% observed in different species of seabirds (this study), 1.2\% in Puffinus puffinus [12], $1.7 \%$ in raptors [28], $0.4 \%$ in Phasianus colchicus [6], and $4.7 \%$ affecting captive/companion birds [30], but it was considered lower when compared to $21.5 \%$ and $23.3 \%$ affecting captive/broilers [36,39]. The difference observed may be influenced by the population analysed (individual x grouped broilers), but also by the gout pathogeny and environmental conditions, including husbandry issues as behavioral, physiological and genetic traits among taxa that may predispose captive birds to diseases [2,10].

Despite the differences cited above, it is well established that visceral gout in birds typically arises from an increase in uric-acid production and/or decreased excretion, leading to hyperuricemia and, with the continuity of this condition, crystal deposition in various tissues [22,38]. A wide range of causes was associated with visceral urate deposition in birds, including nutritional disorders (imbalance of protein intake [16], vitamin A deficiency [38] and excess of calcium intake [16,32]), dehydration $[1,21,38]$, infectious diseases resulting in renal lesions such as cryptosporidiosis [7], nephropathogenic infectious bronchitis [43], chicken astrovirus [3], avian nephritis virus [37] and fowl adenovirus [24], renal neoplasms [26] or ingestion of nephrotoxic substances as oosporein mycotoxin [33], sodium bicarbonate [11], diclofenac $[18,19,44]$ and allopurinol [23].

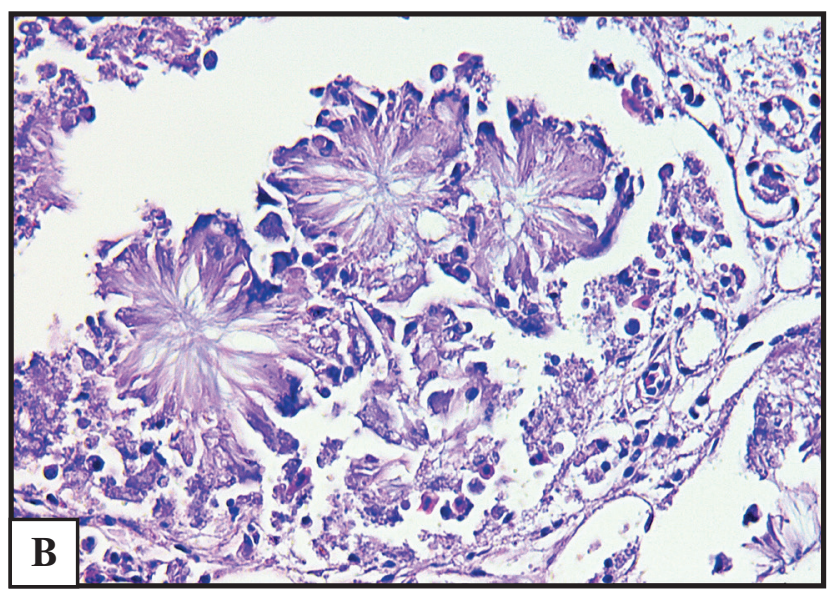

Figure 1. Visceral gout in a male Puffinus puffinus. A- Enlarged and diffusely whitish kidneys associated with the presence of urate crystals. B- Photomicrograph of a section of kidney, showing autolytic changes as well as urate crystals surrounded by necrosis and histiocytic cells. [HE; Obj.400x. $\mathrm{Bar}=50 \mu \mathrm{m}]$. 
Among the possible causes of gout, dehydration was observed in all gout-affetected animals stranded alive, a change usually observed in debilitated/ stranded animals [1] that probably has contributed to the disease. Additionally, the poor/cachectic condition noticed in the majority of seabirds indicates a nutritional disorder, also a cause promoting visceral gout. The catabolism of skeletal muscle is a mechanism for energy supply and consequently increasing uric acid production. In humans, hyperuricemia was associated with emaciation in patients with chronic heart failure [8]. However, gout prevalence was not evaluated in these cases. In an effort to improve the nutritional status, one animal (Fregata magnifiscens) received an overdose of nutritional supplementation. This may have contributed substantially to hyperuricemia and consequent deposition of urate crystals in the kidneys, liver surface and pericardium [16,38].

The possible causes of gout observed here encompass dehydration, nutritional and metabolic imbalance. Furthermore, chronic accumulation of nephrotoxic substances [31], genetic factors as seen in humans [9], and infectious diseases could also have contributed to gout occurrence.

The macroscopic and microscopical findings observed are consistent to visceral gout in birds, reptiles and mammals, characterized by deposition of urates crystals in the pericardium, kidney, liver, spleen, lung, joints and subcutaneous tissue [25]. Birds are predisposed to the condition because they lack the uricase enzyme, thus excreting nitrogenous wastes as uric acid [38]. Visceral gout with deposits of urate crystals on multiple organs, synovial membranes, with no inflammatory reaction is the result of a severe acute condition, leading to high mortality $[17,38]$. In the present study, the accumulation of urate crystals was predominantly limited to the kidneys $(n=8)$, and associated with inflammatory infiltrate, suggesting a chronic process.

Visceral gout is a complex, multifactorial disease affecting both free-living and rehabilitated/ captive seabirds with a mild frequency. The changes are characterized as a chronic condition predominantly limited to the kidney. Nutritional and/or metabolic causes were present in most cases, but trophic imbalances, environmental degradation, and emerging or re-emerging infectious diseases cannot be ruled out. Therefore, further investigation of the incidences, other possible causes, frequency and consequences for coastal and oceanic species is crucial, and particularly for the migratory species assessed here. Such findings are required to understand ecological dynamics and as a precursor to addressing conservation actions to protect animal health and associated habitats.

\section{MANUFACTURER}

${ }^{1}$ Vetnil-Indústria e Comércio de Produtos Veterinários Ltda. Louveira, SP, Brazil.

Acknowledgments. This study was prepared as part of the results obtained by the Beach Monitoring Project of the Santos Basin, state of Paraná, which is a requirement established by the federal environmental licensing division of the Brazilian environmental agency (IBAMA). The work has been made possible by the dedication of the collaborators of this project to obtain information and samples. Acknowledgments are extended to Matt Broadhurst and Selwyn A. Headley for the voluntary manuscript edition and english review.

Declaration of interest. The authors report no conflicts of interest. The authors alone are responsible for the content and writing of the paper.

\section{REFERENCES}

1 Balseiro A., Espi A., Marquez I., Perez V., Ferreras M.C., Marin J.F. \& Prieto J.M. 2005. Pathological features in marine birds affected by the prestige's oil spill in the north of Spain. Journal of Wildife Diseases. 41(2): 371-378.

2 Beaufrure H., Ammersbach M., Reavill D.R., Garner M.M., Heatley J.J., Wakamatsu N., Nevarez J.G. \& Tully Jr. T.N. 2013. Prevalence of and risk factors associated with atherosclerosis in psittacine birds. Journal of the American Veterinary Medical Association. 242(12): 1696-1704.

3 Bulbule N.R., Mandakhalikar K.D., Kapgate S.S., Deshmukh V.V., Schat K.A. \& Chawak M.M. 2013. Role of chicken astrovirus as a causative agent of gout in commercial broilers in India. Avian Pathology. 42(5): 464-473.

4 Campbell T.W. 2015. Peripheral Blood of Birds. In: Campbell T.W. (Ed). Exotic Animal Hematology and Cytology. Ames: John Wiley \& Sons, pp.37-66.

5 Cardoso M.D., Moura J.F., Tavares D.C., Gonzalves R.A., Colabuono F.I., Roges E.M., Souza R.L., Rodrigues D.D.P., Montone R.C. \& Siciliano S. 2014. The Manx shearwater (Puffinus puffinus) as a candidate 
sentinel of Atlantic Ocean health. Aquatic Biosystems. 10(1): 1-10.

6 Curland N., Gethцffer F., van Neer A., Ziegler L., Heffels-Redmann U., Lierz M., Baumgдrtner W., Wohlsein P., Vulker I., Lapp S., Bello A., M. Pfankuche V., Braune S., Runge M., Moss A., Rautenschlein S., Jung A., Teske L., Strube C. \& Siebert U. 2018. Investigation into diseases in free-ranging ring-necked pheasants (Phasianus colchicus) in northwestern Germany during population decline with special reference to infectious pathogens. European Journal of Wildlife Research. 64: 12.

7 Curtiss J.B., Leone A.M., Wellehan Jr. J.F., Emerson J.A., Howerth E.W. \& Farina L.L. 2015. Renal and cloacal cryptosporidiosis (cryptosporidium avian genotype v) in a major mitchell's cockatoo (Lophochroa leadbeateri). Journal of Zoo and Wildlife Medicine. 46(4): 934-937.

8 Doehner W., Rauchhaus M., Florea V.G., Sharma R., Bolger A.P., Davos C.H., Coats A.J. \& Anker S.D. 2001. Uric acid in cachectic and noncachectic patients with chronic heart failure: relationship to leg vascular resistance. American Heart Journal. 141(5): 792-799.

9 Doherty M. 2009. New insights into the epidemiology of gout. Rheumatology (Oxford). 48(Suppl 2): ii2-ii8.

10 Dorrestein G.M. 2009. Bacterial and parasitic diseases of passerines. The veterinary clinics of North America. Exotic Animal Practice. 12(3): 433-451.

11 Ejaz S., Kim B.S. \& Lim C.W. 2005. Gout induced by intoxication of sodium bicarbonate in Korean native broilers. Drug and Chemical Toxicology. 28(2): 245-261.

12 Fink D., Drumond L., Bashlio M.I., Sartori C.M., Andrade T.R., Santos N.Z. \& Cremer M.J. 2018. Gota úrica visceral em bobo-pequeno (Puffinus puffinus) no sul do Brasil. Arquivo Brasileiro de Medicina Veterinária e Zootecnia. 70: 486-490.

13 Fudge A. 1994. Blood testing artifacts: interpretation and prevention. Seminars in Avian and Exotic Pet Medicine. 3(2): 2-4.

14 Gomes A.M. 2010. Padrões de uso e ocorrência de aves associadas ao ambiente aquático no Complexo Estuarino de Paranaguá, Paraná, Brasil, in Sistemas costeiros e oceânicos. 63f. Centro de Estudos do Mar, Universidade Federal do Paraná: Pontal do Paraná, Brasil.

15 Guilford T., Meade J., Willis J., Phillips R.A., Boyle D., Roberts S., Collett M., Freeman R. \& Perrins C.M. 2009. Migration and stopover in a small pelagic seabird, the Manx shearwater Puffinus puffinus: insights from machine learning. Proceedings of the Royal Society B: Biological Sciences. 276(1660): 1215-1223.

16 Guo X., Huang K. \& Tang J. 2005. Clinicopathology of gout in growing layers induced by high calcium and high protein diets. British poultry science. 46(5): 641-646.

17 Herbert J.D., Coulson J.O. \& Coulson T.D. 2011. Quantification of tissue uric acid levels in a Harris's hawk with visceral gout. Avian Diseases. 55(3): 513-515.

18 Hussain I., Khan M.Z., Khan A., Javed I. \& Saleemi M.K. 2008. Toxicological effects of diclofenac in four avian species. Avian Pathology. 37(3): 315-321.

19 Jain T., Koley K.M., Vadlamudi V.P., Ghosh R.C., Roy S., Tiwari S. \& Sahu U. 2009. Diclofenac-induced biochemical and histopathological changes in white leghorn birds (Gallus domesticus). Indian Journal of Pharmacology. 41(5): 237-241.

20 Jencek J.E., Beaufrere H., Tully Jr. T.N., Garner M.M., Dunker F.H. \& Baszler T.V. 2012. An outbreak of Chlamydophila psittaci in an outdoor colony of Magellanic penguins (Spheniscus magellanicus). Journal of avian medicine and surgery. 26(4): 225-231.

21 Julian R. 1982. Water deprivation as a cause of renal disease in chickens. Avian Pathology. 11(4): 615-617.

22 Lumeij J.T. 1994. Nephrology. In: Ritchie B.W., Harrison G.J. \& Harrison L.R. (Eds). Avian medicine. Principles and application. Lake Worth: Wingers Publishing, pp.538-555.

23 Lumeij J.T., Sprang E.P. \& Redig P.T. 1998. Further studies on allopurinol-induced hyperuricaemia and visceral gout in red-tailed hawks (Buteo jamaicensis). Avian Pathology. 27(4): 390-393.

24 Maartens L.H., Joubert H.W., Aitchison H. \& Venter E.H. 2014. Inclusion body hepatitis associated with an outbreak of fowl adenovirus type 2 and type $8 \mathrm{~b}$ in broiler flocks in South Africa. Journal of the South African Veterinary Association. 85(1): e1-e5.

25 Mader D.R. 2006. Gout. In: Mader D.R. (Ed). Reptile Medicine and Surgery. Saint Louis: W.B. Saunders, pp.793-800.

26 Mainez M., Cardona T., Such R., Juan-Salles C. \& Garner M.M. 2015. Bilateral Renal Tubular Neoplasm in a 
Channel-billed Toucan (Ramphastos vitellinus). Journal of avian medicine and surgery. 29(1): 46-50.

27 Moraes V.S. \& Krul R. 1995. Aves associadas a ecossistemas de influência marítima no litoral do Paraná. Arquivos de Biologia e Tecnologia. 38(1): 121-134.

28 Morishita T.Y., Fullerton A.T., Lowenstine L.J., Gardner I.A. \& Brooks D.L. 1998. Morbidity and mortality in free-living raptorial birds of northern California: a retrospective study, 1983-1994. Journal of Avian Medicine and Surgery: 78-81.

29 Murnane R.D. \& Garner M.M. 1987. Visceral gout in a rough legged hawk (Buteo lagopus). Journal of wildlife diseases. 23(3): 515-7.

30 Nemeth N.M., Gonzalez-Astudillo V., Oesterle P.T. \& Howerth E.W. 2016. A 5-Year Retrospective Review of Avian Diseases Diagnosed at the Department of Pathology, University of Georgia. Journal of Comparative Pathology. 155(2-3): 105-120.

31 Nicholson J.K., Kendall M.D. \& Osborn D. 1983. Cadmium and mercury nephrotoxicity. Nature. 304(5927): 633635.

32 Page R.K., Fletcher O.J. \& Bush P. 1979. Calcium toxicosis in broiler chickens. Avian Diseases. 23(4): 1055-1059.

33 Pegram R.A. \& Wyatt R.D. 1981. Avian gout caused by oosporein, a mycotoxin produced by Caetomium trilaterale. Poultry Science. 60(11): 2429-2440.

34 Rahimi M., Minoosh Z. \& Haghighi S. 2015. Visceral urate deposition in a little bittern (Ixobrychus minutus). Veterinary Research Forum. 6(2): 177-180.

35 Sales I.S., Nogueira C.H.O. \& Silveira L.S. 2015. Gota úrica visceral em coruja suindara (Tyto alba) de vida livre. Pesquisa Veterinária Brasileira. 35: 169-172.

36 Sathiyaseelan M., Kumar R., Lakkawar A.W., Nair G., Thanislass J. \& Varshney K.C. 2018. Pathology of Gout in Commercial Broiler Chicken. International Journal of Current Microbiology and Applied Sciences. 7: 2414-2417.

37 Shirai J., Nakamura K., Nozaki H. \& Kawamura H. 1991. Differences in the induction of urate deposition of specific-pathogen-free chicks inoculated with avian nephritis virus passaged by five different methods. Avian Diseases. 35(2): 269-275.

38 Siller W.G. 1981. Renal pathology of the fowl-a review. Avian Pathology. 10(3): 187-262.

39 Singh N., Ghosh R.C. \& Singh A. 2013. Prevalence and haemato-biochemical studies on naturally occurring gout in Chhattisgarh. Advances in Animal and Veterinary Sciences. 1(3S): 9-11.

40 United Nations Educational S.A.C.O.U. 2017. Atlantic Forest South-East Reserves. Available in < http://whc.unesco. org/en/list/893> [Accessed online in July 2019].

41 Vooren C.M. \& Brusque L.F. 1999. As aves do ambiente costeiro do Brasil: biodiversidade e conservação. Trabalho realizado para o Programa Nacional da Diversidade Biológica - PRONABIO, Subprojeto "Avaliação e Ações Prioritárias para a Zona Costeira e Marinha”, Aves marinhas. Brasília: MAM, 58p.

42 Ward F.P. \& Slaughter L.J. 1968. Visceral gout in a captive Cooper's hawk. Wildlife Disease. 4(3): 91-93.

43 Ziegler A.F., Ladman B.S., Dunn P.A., Schneider A., Davison S., Miller P.G., Lu H., Weinstock D., Salem M., Eckroade R.J. \& Gelb Jr. J. 2002. Nephropathogenic infectious bronchitis in Pennsylvania chickens 1997-2000. Avian Diseases. 46(4): 847-858.

44 Zorrilla I., Martinez R., Taggart M.A. \& Richards N. 2015. Suspected flunixin poisoning of a wild Eurasian Griffon Vulture from Spain. Conservation Biology : the Journal of the Society for Conservation Biology. 29(2): 587-592. 